\title{
THE INFLUENCE OF CURRENT RATIO, DEBT TO EQUITY RATIO, AND TOTAL ASSET TURNOVER RATIO ON PROFITABILITY OF TRANSPORTATION COMPANIES LISTED ON THE INDONESIA STOCK EXCHANGE 2014- 2018
}

\author{
Talisa, QAMARA \\ Faculty of Economics and Business, Narotama University, Surabaya, Indonesia \\ qamaratalisa19@gmail.com \\ Ani, WULANDARI \\ Faculty of Economics and Business, Narotama University, Surabaya, Indonesia \\ ani.wulandari@narotama.ac.id \\ Agus, SUKOCO \\ Faculty of Economics and Business, Narotama University, Surabaya, Indonesia \\ Agus.sukoco@narotama.ac.id \\ Joko, SUYONO \\ Faculty of Economics and Business, Narotama University, Surabaya, Indonesia \\ Joko.suyono@narotama.ac.id
}

\begin{abstract}
This study aims to analyze whether there are simultaneous effects of Current Ratio, Debt to Equity Ratio, and Total Asset Turnover to Pofitability (Return On Asset) on Transportation Company Listed at Indonesia Stock Exchanged. This research use quantitative method. The population on this research is transportation companies listed at Indonesia Stock Exchange (IDX) and continuously published financial reports in 2014-2018. Based on the purposive sampling method, from 71 transportation companies globally converged into 10 transportation companies, so that the data obtained were 50 observation. The analytical method used is multiple linear regression analysis. The results of the study are Current Ratio and Debt to Equity Ratio does not partially affect ROA, while Total Asset Turnover has a partial effect on ROA. And the three independent variables (CR, DER and TATO) simultaneously influence the dependent variable, namely profitability (ROA).
\end{abstract}

Keywords:Profitability, Logistics, Liquidity, Leverage, Transportation

\section{INTRODUCTION}

The development of transportation company nowadays colored by increasing intense competition between providers. Public has set an increasingly high standard for safety and comfort of transportation so that service providers inevitably have to be able to follow request of consumers if they still want to survive in the transportation industry by improving the quality and reliability of services that are owned by consumers. Innovation and creativity are also influencially in this case because there are many opportunities to attract consumer interest. Companies must be able to compete in a healthy manner with other competitors through effective performance improvements and companies must be able to maintain the stability of capital turnover and company profitability. The health of a company can be value from the total debt, the less of total debt, it is mean the healthier company. 
Liquidity Ratio is the most widely used on financial statement analysis technique. This ratio is an analytical tool that can be provide a way out and describe the symptoms (visible symptoms) of a situation. In other word, the ratio can also show areas that require more in-depth research and treatment. Ratio analysis can reveal relationships and at the same time become a basis for comparison that shows conditions or trends that cannot be detected if we only see the ratio component itself. This ratio analysis aims to assess the effectiveness of decisions that have been taken by the company in order to carry out its business activities. Ratio analysis of financial statements commonly used is liquidity ratio analysis, solvability ratio analysis, activity ratio analysis and profitability ratio analysis.

According to I Made Sudana (2011:22) Profitability is "the company's ability to generate profits by using resources owned such as assets, capital or company sales. Profitability or profit is one ratio that can be influenced by company performance through financial performance and other financial ratio. These ratio'swill later be used as a measure of the company's success in carrying out its operations and measuring the level of success of the company in managing assets and profits earned.

Current Ratio (CR) is a ratio that measures the financial performance of a company's liquidity. This Current Ratio shows the company's ability to meet its short-term debt obligations in the next 12 months. Prospective creditors generally use this ratio to determine whether to make a short-term loan or not to the company concerned. Current ratio also shows the efficiency of the company's operating cycle or its ability to convert products into cash. Current Ratio or Current Ratio which is one of the Liquidity Ratio Analysis is also known as the working capital ratio.

Debt to Equity (DER) is the financial ratio chosen as a representative of the solvency ratio where in this ratio as a comparison of capital obtained by the company both from the internal, namely the stake holder or external, namely the creditor. According to Kasmir (2014: 157), states that: Debt to equity ratio is a ratio used to assess debt with equity. This ratio is sought by comparing all debt, including current debt with all equity. This ratio is used to determine the amount of funds provided by the borrower (creditor) with the owner of the company. In other words, this ratio serves to know every rupiah of its own capital which is used as collateral for debt.

Total Asset Turn Over (TATO) is one of the activity ratios, namely the company's ability to know the effectiveness of the use of assets in generating sales and measuring the turnover of all assets owned by the company and measuring how many sales are obtained from each rupiah of assets. According to Fahmi (2012: 135) this ratio sees the extent to which the overall assets owned by the company occur in circulation effectively. While according to Moeldjadi (2008: 50) define that Total Asset Turnover shows the ability of total assets to spin for one year to produce sales that can be calculated by dividing net sales by the average total assets. From the definition above, it can be concluded that Total Asset Turnover is a ratio that is used to see the total ability of rotating assets for one year in generating sales from a company.

The selection of the transportation sector as a research sample is considering to transportation companies are one type of business that is growing rapidly in Indonesia. It has been predicted that in 2019 the transportation industry will experience an increase from the previous year. Supply Chain Indonesia (SCI) predicts the Indonesian transportation sector in 2019 will grow by $11.15 \%$, which in 2018 was recorded at Rp. 666.2 trillion, in 2019 it increased by Rp. 740.4 trillion. The contribution of land transportation is still the biggest in the growth of the transportation service sector with the amount of Rp. 380.8 trillion or around $51.43 \%$ of air transportation which is only Rp. 282.2 trillion or around $38.12 \%$, sea transportation is $6.50 \%$. This study aims to determine whether there is a simultaneous influence of Current Ratio (CR), Debt To Equity Ratio (DER), and Total Asset Turnover (TATO) on the Profitability of Return On Assets (ROA). This research is expected to provide benefits as a source of information and consideration for companies in predicting financial performance in a company. 
Based on the phenomena and theories and previous research regarding factors that can affect profitability. The ratios above are a small part of many ratios that affect financial performance, profitability and others as such, but based on previous research on the transportation sector there is no one that discusses the effect of Current Ratio, Debt to Equity and Total Asset Turn Over on public transport and logistics companies listed on the IDX, tertatrik researchers carry out research with the title "The Influence of Current Ratio, Debt to Equity Ratio, and Total Asset Turnover Ratio on Profitability of Transportation Companies Listed on the Indonesia Stock Exchange 2014-2018"

Based on the background described above, the problems that will be examined in this study can be determined, namely:

1. Does Current Ratio partially influence the profitability of transportation companies listed on the Indonesia Stock Exchange in 2014-2018?

2. DoesDebt to Equity Ratio partially influence the profitabilityof transportation companies listed on the Indonesia Stock Exchange in 2014-2018?

3. DoesTotal Asset Turnover influence the profitability of trasnportation companies listed on the Indonesia Stock Exchange in 2014-2018?

4. DoesCurrent Ratio, Debt to Equity Ratio and Total Asset Turnover simultaneously influencing the profitability of trasnportation companies listed on the Indonesia Stock Exchange in 2014-2018?

\section{LITERATURE REVIEWS AND HYPOTHESES}

Ken Aditya andlsnurhadi 2016, conducted research with tittle Analysis of Current Ratio, Total Asset Turnover Ratio, Debt to Equity Return on Equity and Earning Per Share Against Returns on Company Stock Infrastructure, Utilities, and Transportation Sectors Registered on the Indonesia Stock Exchange Period 2007-2011 with result are the five independent variables examined together did not have an influence on infrastructure stock returns, utilities, and transportation from 2007-2011. Made Sumiartini, WayanCiptaandWayanSuwendra conduct research with tittle The Influences of Company Size and Capital Structure on Corporate Values in Transportation Sector Companies Listed on the Indonesia Stock Exchange. The results showed that there was a significant influence between company size (X1), and capital structure (X2) on firm value (Y) in transportation sector companies listed on the IDX.

Yulius Ardy Wiranata and Yeterina Widi Nugrahanti in 2017 with the title "The Influenced of Ownership Structure on the Profitability of Manufacturing Companies in Indonesia".The results of the study, namely testing showed that foreign ownership and leverage were affected positively on company profitability, while family ownership had a negative influence on the profitability of the company. However, other variables, namely government ownership, management ownership, institutional ownership and company size were not proven to affect profitability. The research conducted by Cyrillius Martono in 2016 entitled "Analysis of the Effect of Industry Profitability, Weighted Financial Leverage Ratio and Weighted Capital Intensity and Market Share on ROA and ROE of GO PUBLIC Manufacturing Companies on the Indonesia Stock Exchange". The results of the study are that the profitability of the industry proved superior in explaining ROA, while the variables that were superior in explaining ROE were weighted financial leverage ratios.

\section{Current Ratio}

According to Kasmir (2015: 134), Current Ratio is a ratio to measure a company's ability to pay short-term debt or debt that is immediately due when billed as a whole. Or in other words, how much current assets are available to cover short-term liabilities that are immediately due date.

Current Ratio (CR) is also referred to as a short-term ratio. This ratio helps to understand liquidity in business which is a potential ability to fulfill current obligations and also as a comparison between current assets and current debt. This ratio expresses the 
relationship between current assets and current assets from business concerns during a certain period. The formula of the Cuurent Ratio is as follows:

$$
\text { Current Ratio }=\frac{\text { Current Asset }}{\text { Current Liability }} \times 100 \%
$$

\section{Debt to Equity Ratio}

Debt to Equity Ratio is part of the Leverage ratio. Debt to Equity Ratio is the ratio used to assess debt with equity. In other words, this ratio serves to know every rupiah of its own capital which is used as collateral for debt. For creditors, the greater the ratio, the more unprofitable because the greater the risk borne for failures that may occur in the company. But for companies the greater the ratio, the better.

Kasmir (2015) states that Debt to Equity Ratio is a ratio used to assess debt with equity. This ratio is calculated by comparing all debts including current debt with all equity. This ratio is useful to know that every rupiah of your own capital is used as collateral for debt. The lower the DER, the higher the company's ability to pay all its obligations. The greater the proportion of debt used for the capital structure of a company, the greater the number of obligations. The following formula for measuring the debt to equity ratio (DER) according to Gitman (2009) as below :

$$
\text { Debt to Equity }=\frac{\text { Total Liability }}{\text { "Total Equity" }} \times 100 \%
$$

\section{Total Asset Turnover}

Total Assets Turnover is a ratio used to measure the total effectiveness of assets owned by a company in generating sales, or in other words to measure how many sales will be generated from each rupiah fund embedded in total assets.Syamsudin (2011) states that the total asset turnover ratio shows the efficiency of the overall use of company assets in generating certain sales volumes. If the turnover is slow, it means that the assets owned are too large compared to the level of sales of the company. The higher the total assets turnover, the more efficient use of these assets. The formula for calculating total asset turnover according to Kasmir (2016) as below :

$$
\text { Total Asset Turnover }=\frac{\text { Sales }}{\text { Total Asset }} \times 100 \%
$$

\section{Profitability (ROA)}

Profitability ratios needed to record financial transactions are usually assessed by investors and creditors (banks) to assess the amount of investment profits that will be obtained by investors and the company's profit to assess the ability of companies to pay debts to creditors based on the level of use of assets and other resources so that it looks level of company efficiency. (Margaretha, 2005: 21). The formula used to find the Return On Asset ratio is as follows::

$$
\text { ReturnOn Assets }=\frac{\text { Net Profit }}{\text { Total Assets }} \times 100 \%
$$




\section{Hypothesis}

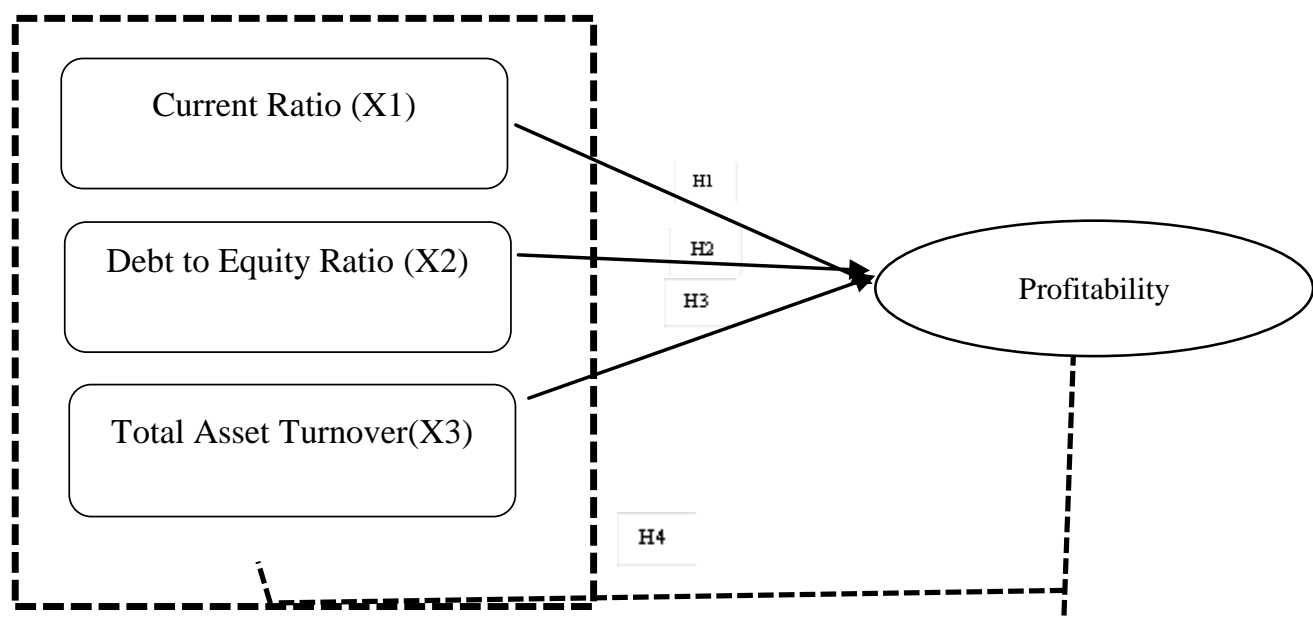

Figure 1. Research Model

Based on the theoretical basis and the framework of thinking that has been described above, the hypothesis of this study are:

$\mathrm{H} 1$ : Current Ratio has a positive and significant influence on profitability of trasnportation companies listed on the Indonesia Stock Exchange in 20142018.

H2: Debt to Equity Ratio has a positive and significant influence on profitability of transportation companies listed on the Indonesia Stock Exchange in 20142018.

H3: Total Asset Turnover Ratio has a positive and significant influence on profitability of transportation companies listed on the Indonesia Stock Exchange in 20142018.

H4: Current Ratio, Debt ti Equity Ratio and Total Asset Turnover simultaneously have a positive and significant influence on profitability of trasnportation companies listed on the Indonesia Stock Exchange in 2014-2018.

\section{RESEARCH METHODS}

\section{Types of research}

This type of research is quantitative associative. According to Sugiyono (2013:11) Quantitative methods can be interpreted as research methods based on the philosophy of positivism, used to examine certain populations or samples, data collection using research instruments, quantitative / statistical data analysis, with the aim of testing hypotheses that have been set. This research used quantitative because the variable used is more than one variable.

\section{Population}

Population is a generalization area consisting of objects / subjects that have certain qualities and characteristics set by the researcher to be studied and then conclusions drawn (Sugiyono: 2013. The population in this study are transportation companies listed on the Indonesia Stock Exchange.

\section{Sample}

Sample is part of the number and characteristics of the population. The sampling technique used is Nonprobability Sampling (purposive sampling). The sample in this study is 
a Trasnportation Company registered on the Indonesia Stock Exchange which reports consecutive and audited Financial Statements from 2014-2018.

\section{Data Type}

According to Sugiyono (2013) secondary data is data that does not directly provide data to data collectors, for example through other people or through documents collected from hand to two or from other sources that were available before the research was conducted in this study secondary data obtained from reference books, journals, thesis..

\section{Data Source}

The data sources in this study are secondary data obtained from the Indonesia Stock Exchange website (www.idx.co.id), and www.sahamok.com.

\section{Data Collection}

According to Sugiyono (2013: 187) data collection techniques can be done in various settings, various sources, and various ways. when viewed from the data source, data collection can use primary and secondary sources. Furthermore, when viewed in terms of methods or techniques of data collection, the data collection technique can be done by interview, questionnaire, observation and a combination of that three techniques.

\section{Data Analysis Technique}

In quantitative research, the data analysis technique used is clear, that is directed to answer the problem statement or test the hypothesis that has been formulated in the proposal. Because the data is quantitative, the data analysis technique uses statistical methods that are already available. For example, it will test the hypothesis of the relationship between two variables, if the data is ordinal, then the statistics used are Spearman Rank Correlation, while the data is interval or ratio used Pearson Product Moment Correlation. If you are going to test the significance of the comparability of the data of two samples, if the data is nominally used, Chi Square. Furthermore, if you will test the comparative hypothesis more than two samples, the data is interval, Variant Analysis is used.

\begin{tabular}{ll} 
& \multicolumn{1}{c}{$\mathbf{Y}=\boldsymbol{\beta} \mathbf{0}+\boldsymbol{\beta} \mathbf{X} \mathbf{1}+\boldsymbol{\beta} \mathbf{2} \mathbf{2} \mathbf{2}+\boldsymbol{\beta} \mathbf{3} \mathbf{X} \mathbf{3}+\mathbf{e}$} \\
$\mathrm{Y}$ & $:$ Company Financial Performance \\
$\mathrm{X} 1$ & $:$ Managerial Ownership \\
$\mathrm{X} 2$ & $:$ Institutional Ownership \\
$\mathrm{X}_{3}$ & $:$ Dividend Policy \\
$\beta 0$ & $:$ Intercept (Constant) \\
$\beta 1, \beta 2, \beta 3$ & $:$ Regression Coefficient. \\
$\mathrm{e}$ & $:$ Error
\end{tabular}

\section{RESULTS AND DISCUSSION}

\section{Descriptive Statistics}

Descriptive statistics function to provide an overview or description of a research data that can be seen from the average value, standard deviation, maximum value and minimum value. The results of descriptive statistics are shown in the table as follows: 
Table 1. Descriptive Statistics Results

\begin{tabular}{|l|r|r|r|r|r|}
\hline \multicolumn{1}{|c|}{ Model } & N & Minimum & Maximum & Mean & Deviation \\
\hline Current Ratio & 50 & .00 & 6.01 & 1.4441 & 1.27624 \\
\hline Debt to Equity Ratio & 50 & .00 & 4.30 & 1.1494 & 1.15013 \\
\hline Total Asset Turnover & 50 & .00 & 1.40 & .3349 & .31051 \\
\hline Valid N (listwise) & 50 & & & & \\
\hline
\end{tabular}

Source : Output SPSS 2019

Based on descriptive table statistics above shows that of the 10 trasnportation companies with 50 observation data over a period of 5 years namely 2014-2018, Current Ratio (X1) has a minimum value of 0.00 , a maximum value of 6.01 , and an average value of 1.44 with a standard deviation of 1.28. Debt to Equity Ratio (X2) has a minimum value of 0.00 , a maximum value of 4.30 , and an average value of 1.14 with a standard deviation of 1.15. Total Asset Turnover (X3) has a minimum value of 0.00 , a maximum value of 1.40 , and an average value of 0.33 with a standard deviation of 0.31 . Then it can be interpreted that the data used in this study can be distributed normally.

\section{Multicollinearity Test}

Multicollinearity test can be done by looking at the value of toolerance and variance inflating factor (VIF). The following is the result of testing multiple linear regression models in this study:

Tabel 2: Multicollinearity Test Results

\begin{tabular}{|l|c|c|c|c|c|}
\hline \multirow{2}{*}{ Model } & \multicolumn{2}{|c|}{$\begin{array}{c}\text { Undstandardized } \\
\text { Coefficient }\end{array}$} & $\begin{array}{c}\text { Standardized } \\
\text { Coefficient }\end{array}$ & \multicolumn{2}{c|}{$\begin{array}{c}\text { Collinearity } \\
\text { Statistics }\end{array}$} \\
\cline { 2 - 6 } & B & $\begin{array}{c}\text { Std } \\
\text { Error }\end{array}$ & Beta & Tolerance & VIF \\
\hline Constant & $-0,060$ & 0,023 & & & \\
\hline Current Ratio & 0,166 & 0,084 & 0,245 & 0,964 & 1,038 \\
\hline Debt to Equity Ratio & 0,176 & 0,092 & 0,233 & 0,981 & 1,019 \\
\hline Total Asset Turnover & 1,056 & 0,345 & 0,379 & 0,961 & 1,040 \\
\hline
\end{tabular}

\section{Source :Ouput SPSS 2019}

Based on the Coefficient table above the tolerance value of the Current Ratio variable is $0.964>0.10$ and the VIF value is $1.038<10.00$. The tolerance value of the DER variable (Debt to Equity Ratio) is $0.981>0.10$ and the VIF value is $1.019<10.00$.And the variable tolerance value TATO (Total Asset Turnover) is $0.961>0.10$ and VIF value is 1.040 $<10.00$. So the conclusion is that the three variables do not occur with multicolourearity symptoms in the regression model.

\section{Heteroscedasticity Test}

Heteroscedaticity test results of this test aim to find out whether in the regression model there is a residual variance error of one variable with other variables. The following are the results of heteroscedasticity tests in table form. The following is the result of testing multiple linear regression models in this study: 
Tabel 3:Heteroscedasticity Test Results

\begin{tabular}{|l|c|c|c|c|c|}
\hline \multirow{2}{*}{ Model } & \multicolumn{2}{|c|}{$\begin{array}{c}\text { Undstandardized } \\
\text { Coefficient }\end{array}$} & $\begin{array}{c}\text { Standardized } \\
\text { Coefficient }\end{array}$ & & \multirow{2}{*}{ Std } \\
\cline { 2 - 5 } & B & $\begin{array}{c}\text { Stror } \\
\text { Error }\end{array}$ & Beta & t & Sig. \\
\hline Constant & 0,033 & 0,087 & & 1,850 & 0,768 \\
\hline Current Ratio & 0,225 & 0,036 & 0,583 & 1,981 & 0,054 \\
\hline Debt to Equity Ratio & 0,209 & 0,040 & 0,488 & 1,903 & 0,063 \\
\hline Total Asset Turn Over & 0,267 & 0,149 & 0,168 & 3,060 & 0,080 \\
\hline
\end{tabular}

Based on the table of Coefficient above the value of the significance of the Current Ratio variable is 0.054 . The value of the Debt to Equity Ratio variable is 0.063 . And the value of Total Asset Turnover significance is 0.080 The three independent variables in this study obtained a significance value $>0.05$. So, it can be concluded that the regression model in this study did not occur heteroscedasticity.

\section{Autocorrelation Test}

This test discusses in testing whether in the linear regression model it has correlation between disturbing errors in period $t$ and period $t-1$. And to find out if there are conflicts between variables that are used in the prediction model with changes in the time supported. The following is the result of testing multiple linear regression models in this study:

Tabel 4: Autocorrelation Test Results

\begin{tabular}{|c|c|c|c|c|c|}
\hline Model & $\mathbf{R}$ & $\begin{array}{c}\mathbf{R} \\
\text { Square }\end{array}$ & $\begin{array}{c}\text { Adjusted } \\
\mathbf{R} \\
\text { Square }\end{array}$ & $\begin{array}{c}\text { Std error } \\
\text { of the } \\
\text { Estimate }\end{array}$ & $\begin{array}{c}\text { Durbin- } \\
\text { watson }\end{array}$ \\
\hline 1 & $0,567 a$ & 0,321 & 0,277 & 0,735 & 0,825 \\
\hline
\end{tabular}

From the results of the autocorrelation test above, the value of durbin watson is 0.825 . Independent variables used are 3 variables $(k=3)$, and observation data as many as 50 data then $(\mathrm{N}=50)$. Therefore the value of $\mathrm{dL}$ or lower limit of 1.421 and the value of $\mathrm{dU}$ or upper limit of 1.674 and the value of $4-\mathrm{dU}$ is 1.721 . Therefore it can be concluded that there is no autocorrelation because the value of durbin watson is smaller than the 4-dU value.

\section{Normality Test}

Normality test using SPSS software by reading the kolmogorov-smirnov table. The following is the result of testing multiple linear regression models in this study:

\section{One Sample KolmogrovSmirnovTest}

\begin{tabular}{|ll|r|}
\hline & & $\begin{array}{c}\text { Undstandardized } \\
\text { Residual }\end{array}$ \\
\hline Normal Parameters & Mean & 50 \\
& Std & 0,000 \\
Most Extreme Different & Deviation & 0,71252385 \\
& Absolute & 0,166 \\
& Positive & 0,166 \\
Kolmogrov Smirnov Z & Negative & $-0,117$ \\
Asymp. Sig (2 tailed) & & 1,177 \\
\hline
\end{tabular}


Based on the results in the table above, it can be concluded that the value of Asymp. Sig is 0.125 . Due to the value of Asymp. Sig is smaller than 0.05 so the distribution of variables in this study is declared normal.

\section{Simultaneous Hypothesis Test (F Test )}

The $F$ test is a test used to determine the effect of simultaneous independent variables on the dependent variable. The following are the results of this research's $F$ test:

\begin{tabular}{|l|c|c|c|c|c|}
\multicolumn{1}{c|}{ ANOVA } \\
\multicolumn{1}{|c|}{ Model } & $\begin{array}{c}\text { Sum of } \\
\text { Squares }\end{array}$ & df & $\begin{array}{c}\text { Mean } \\
\text { Square }\end{array}$ & F & Sig. \\
\hline Regression & 11,771 & 3 & 3,924 & 7,255 & $0,000^{\text {a }}$ \\
\hline Residual & 24,877 & 46 & 0,541 & & \\
\hline Total & 36,648 & 49 & & & \\
\hline
\end{tabular}

Based on the ANOVA table above the significance value the results of the $F$ test is 7,255 and the calculated $F$ value is $4,35 . F$ table can be searched using the formula $(k ; n-k)$. Known $\mathrm{k}$ is the number of independent variables in the study, while $\mathrm{n}$ is the number of study samples. So, $(\mathrm{k}: \mathrm{n}-\mathrm{k})$, that is $(3 ; 10-3)$. The table $\mathrm{F}$ value is 4,35 . So, it can be concluded that the hypothesis is accepted, based on the calculated $F$ value which is greater than the value of the $F$ table (7255> 4.35) and the significance of 0.05 according to the standard basic decision-making data.

\section{Partial Hypothesis Test (t Test)}

The $t$ test is a test used to determine whether the independent variable partially influences the dependent variable. The following are the results of this research $t$ test:

\begin{tabular}{|l|c|c|c|c|c|}
\hline \multirow{2}{*}{ Model } & \multicolumn{2}{c|}{$\begin{array}{c}\text { Undstandardized } \\
\text { Coefficient }\end{array}$} & $\begin{array}{c}\text { Standardized } \\
\text { Coefficient }\end{array}$ & & \\
\cline { 2 - 6 } & B & $\begin{array}{c}\text { Std } \\
\text { Error }\end{array}$ & Beta & t & Sig. \\
\hline Constant & $-0,60$ & 0,203 & & - & \\
\hline Current Ratio & 0,166 & 0,084 & 0,245 & 1,981 & 0,054 \\
\hline Debt to Equity Ratio & 0,176 & 0,092 & 0,233 & 1.903 & 0,063 \\
\hline $\begin{array}{l}\text { Total Asset } \\
\text { Turnover }\end{array}$ & 1,056 & 0,345 & 0,379 & 3,060 & 0,004 \\
\hline
\end{tabular}

Source : Output SPSS 2019

\section{Tabel: t Test Results}

Based on the coefficient table above the value of the significance of Current Ratio variable is 0.054 and the calculated $t$ value is 1,981 . The significance value of Debt to Equity Ratio variable is 0.063 and the value of t count is 0.146 . And the value of the dividend policy significance is 0.041 and the calculated $t$ value is 1,903 . The value of $t$ table can be searched using the following formula $t$ table $=(\alpha / 2$; df residual) obtained by numbers $(0.025 ; 46)$ In the distribution table $t$ it is known that the value of $t$ table is 2,01290 . So it can be concluded that CurrentRatio (X1)HO is accepted and $\mathrm{H} 1$ is rejected due the significant value is bigger the 0,05 , so it is mean that $C R$ does not partially affect ROA (Y).Debt to Equity Ratio $(\mathrm{X} 2) \mathrm{HO}$ is accepted $\mathrm{H} 2$ is rejected due the significant value is bigger then 0,05 , 
then DER does not partially affect ROA $(Y)$. Total Asset Turnover (X3)H0 is rejected H3 is accepted due the significant value is less then 0,05 then TATO has a partial effect on ROA $(\mathrm{Y})$.

\section{Determination Coefficient Test $\left(\mathbf{R}^{2}\right)$}

The coefficient of determination test is used to determine how much influence the independent variable has on the dependent variable. The main requirements so that the test of the coefficient of determination can be used is the result of the $F$ test indicating the simultaneous influence of independent variables on the dependent variable or can also be called the accepted hypothesis. The following are the test results of the coefficient of determination:

\begin{tabular}{|c|c|c|c|c|}
\hline \multicolumn{1}{|c}{ Model Summary } \\
\hline Model & $\mathbf{R}$ & $\begin{array}{c}\mathbf{R} \\
\text { Square }\end{array}$ & $\begin{array}{c}\text { Adjusted R } \\
\text { Square }\end{array}$ & $\begin{array}{c}\text { Std error of } \\
\text { the Estimate }\end{array}$ \\
\hline 1 & $0,567^{\mathrm{a}}$ & 0,321 & 0,277 & 0,735 \\
\hline
\end{tabular}

\section{Determination Coefficient Test Results}

Based on the above table it is known the value of $R$ Square or the coefficient of determination is 0.567 . It can be concluded that the independent variables simultaneously in this study affect the dependent variable by $56,7 \%$.

\section{Multiple Linear Regression Analysis}

Multiple linear regression analysis is used to determine whether there are influences of two or more independent variables on the dependent variable. This study uses three independent variables and one dependent variable. The following is a summary of the results of multiple linear regression analysis based on the tests conducted in this study:

\section{Summary of Results of Multiple Linear Regression Analysis}

\begin{tabular}{|c|c|c|c|}
\hline \multicolumn{4}{|c|}{ Summary of Results of Multiple Linear Regression Analysis } \\
\hline Variable & Regression Coefficient & t count & Sig \\
\hline Constant & $-0,060$ & & \\
\hline Current Ratio & 0,166 & 1,981 & 0,054 \\
\hline Debt to Equity Ratio & 0,176 & 1,903 & 0,063 \\
\hline Total Asset Turnover & 1,056 & 3,060 & 0,004 \\
\hline F count & 7,255 & & \\
\hline R Square & 0,567 & & \\
\hline
\end{tabular}

Based on the table above it can be concluded that the multiple linear regression equation in this study is as follows:

$$
Y=-0,060+0,166+0,176+1,056
$$

Regression coefficients that show positive results indicate that the independent variable changes toward the dependent variable. While the regression coefficients that have negative results indicate that the independent variable is not in line with the dependent variable. In the 
regression equation obtained from the above calculation shows the current ratio variable, debt to equity ratio and total asset turnover has a positive regression coefficient which means that the three variables directly influence the profitability of the company.

The following is the discussion of the results of multiple linear regression analysis of each independent variable on the dependent variable:

\section{Current Ratio and Profitability}

Based on the results of data processing using SPSS software, it can be concluded that CR is not significant towards ROA but has a positive effect. Current Ratio is to assess the company's total current assets, whereas in transportation companies in general the current assets are highly liquid, therefore the Current Ratio does not significantly influence the profitability of the company

\section{Debt to Equity Ratio and Profitability}

Based on the results of data processing using SPSS software, it can be concluded that DER is not significant for ROA but has a positive effect. DER is a ratio used to see the level of capital obtained from stakeholders and creditors, and this does not seem to have any significance to the profitability of the company, especially those engaged in the transportation sector.

\section{Dividend Policy and Financial Performance}

Based on the results of the research using SPSS software, the conclusions obtained, namely TATO, have a partial and positive effect on profitability (ROA). TATO is a ratio to assess the sales level of a company. Own sales for transportation companies greatly affect and affect the profitability of the company, the higher the TATO, the higher the ROA value.

\section{Current Ratio, Debt to Equity Ratio, Total Asset Turnover and Profitability (ROA)}

From the results of this study it can be concluded that CR, DER, and TATO as independent variables $(X)$ have a simultaneous effect and are positive for ROA as the dependent variable $(Y)$. It can be interpreted that each variable has an effect even though it is not large but gives a positive value to the profitability of the company. Although not significant, the three independent variable elements together can have a good influence.

\section{CONCLUSION}

.Based on the problems formulated, the initial hypothesis made, the research method test and the results of the analysis of the tests conducted in the previous chapter, the results of this study can be summarized as follows:

1. Partially current ratio hasnot significant influence on profitability (ROA) of trasnportation companies listed on the Indonesia Stock Exchange in 2014-2018.

2. Partially debt to equity ratio has not significant influence on of construction and building companies listed on the Indonesia Stock Exchange in 2013-2017.

3. Partially Total Asset Turnover has significant influence onprofitability (ROA) of transportation companies listed on the Indonesia Stock Exchange in 2014-2018.

4. Simultaneously current ratio, debt to equity ratio, and total asset turnover have a positive and significant influence on profitability (ROA) of trasnportation companies listed on the Indonesia Stock Exchange in 2014-2018.

\section{REFERENCE}

Bayaraa, B. (2017). Financial Performance Determinants of Organizations: The Case of Mongolian Companies. Journal of Competitiveness, 9(3), 22-33. https://doi.org/10.7441/joc.2017.03.02

ELYAS SETIAWAN. (2015). Pengaruh Current Ratio, Inventory Ratio, Total Asset Turnover, 
Sales, dan Firm Size Terhadap ROA Pada Perusahaan Food and Baverage Yang Terdaftar Di Bursa Efek Indonesia (BEI) Periode 2010-2013. -, 5.

Ifa Nurmasari. (2017). Analisis Current Ratio, Return On Equity, Debt To Equity Ratio Dan Pertumbuhan Pendapatan Berpengaruh Terhadap Return Saham Pada Perusahan Pertambangan Di Bursa Efek Indonesia (BEI) 2010-2014. ISSN, 05.

Komala, L. A. P., \& Nugroho, P. I. (2013). The Effects of Profitability Ratio , Liquidity , and Debt towards Investment Return. Journal of Business and Economics, 4(11), 11761186.

made sumartini, wayan cipta, i wayan suwendra. (2016). Pengaruh Ukuran Perusahaan Dan Struktur Modal Terhadap Nilai Perusahaan Pada Perusahan Sektor Transportasi Yang Terdaftar Di Bursa Efek Indonesia. 4(1).

Martono, C. (2002). Intensitas Modal Tertimbang Serta Perusahaan Manufaktur Yang GoPublic. Jurnal Akuntansi \& Keuangan, 4(2), 126-140.

Mawardi. (2018). Pengaruh Struktur Modal, Total Asset Turnover, Dan Likuiditas Terhadap Nilai Perusahaan Dengan Profitabilitas Sebagai Variabel Intervening (Studi Empiris pada Perusahaan Real Estate dan Properti yang Terdaftar di BEI Periode 2013-2016). ISSN.

Mujahid, M., Haider, F. K., Bba, H., \& Abbas, M. D. (2014). Impact of Privatization of Banks on Profitability of Banking Sector in Pakistan. Issn, 5(24), 2222-1700. Retrieved from www.iiste.org

Nurul Syafangatun. (2016). Pengaruh ROA, ROE,ROI dan EPS Terhadap Harga Saham Perusahaan Pertambangn Batu Bara Yang Terdaftar Di Bursa Efek Indonesia (BEI) Periode 2010-2015. Skripsi, 8.

Paramasivan dan Subramanian. (2015). Financial Management. New Delhi: New Age International Limited.

Pramesti, D., Wijayanti, A., \& Nurlaela, S. (2016). Pengaruh Rasio Likuiditas, Leverage, Aktivitas Dan Firm Size Terhadap Profitabilitas Perusahaan Sub Sektor Otomotif Dan Komponen Di Bursa Efek Indonesia. Seminar Nasional IENACO, (2012), 810-817. Retrieved from https://publikasiilmiah.ums.ac.id/handle/11617/7162

Pramesti1*, D., Wijayanti2, A., \& Siti Nurlaela3. (2016). Pengaruh Rasio Likuiditas, Leverage, Aktivitas Dan Firm Size Terhadap Profitabilitas Peruahaan Sub Sektor Otomotif Dan Komponen Di Bursa Efek Indonesia (BEI). ISSN.

Purwohandoko. (2017). The Influence of Firm's Size, Growth, and Profitability on Firm Value with Capital Structure as the Mediator: A Study on the Agricultural Firms Listed in the Indonesian Stock Exchange. International Journal of Economics and Finance, 9(8), 103. https://doi.org/10.5539/ijef.v9n8p103

R.1), R. A. S., Puspitaningtyas2), Z., \& dan Aryo Prakoso3). (2018). Pengaruh Current Ratio, Total Asset Turnover Dan Debt To Equity Ratio Terhadap Price To Book Value Dengan Return On Asset Sebagai Variabel Intervening (Studi Pada Perusahaan Sektor Industri Barang Konsumsi di Bursa Efek Indonesia Periode 2013-2017). ISSN, 11, 7.

Ristardi, M. (2008). Analisis Laporan Keuangan Untuk Menilai Kinerja Perusahaan. https://doi.org/10.1046/j.1365-2494.2003.00352.x

Riyanto, A. (2018). Implikasi Kualitas Pelayanan Dalam Meningkatkan Kepuasan Pelanggan Pada PDAM Cibadak Sukabumi. 2(1), 117-124. Retrieved from https://ejournal.bsi.ac.id/ejurnal/index.php/ecodemica/article/view/2911

Rizwan Ali Khan \& Mutahhar Ali. (2016). Impact of Liquidity on Profitability of Commercial Banks in Pakistan: An Analysis on Banking Sector in Pakistan. ISSN, 16(1), 2-3.

Shaferi, I., \& Handayani, S. R. (2013). Identifikasi Pengelolaan Keuangan Terhadap Peluang Usaha Online. Ekonomi Dan Bisnis, 846-851.

Shao, Q. (2015). The Analysis of Financial Business Strategy Based on Internet Thinking. Analysis.

Retrieved from /citations?view_op=view_citation\&continue=/scholar\%3Fhl\%3Den\%26as_sdt\%3D0,5\% 26scilib\%3D1\&citilm=1\&citation_for_view=cQ0Vrw8AAAAJ:q3CdL3|zO_QC\&hl=en\&oi= $\mathrm{p}$ 
Sudana, I. M. (2016). Pengaruh Faktor Spesifik Terhadap Profitabilitas Berdasarkan Kelompok Buku Bank di Indonesia. 4(3).

VINTILĂ, G., \& Florinita, D. (2012). The Impact of Financial Leverage to Profitability Study of Companies Listed in Bucharest Stock Exchange. Economic Sciences Series, 12(1), 1741-1744. Retrieved from https://www.researchgate.net/publication/235991927

Wiranata, Y. A., \& Nugrahanti, Y. W. (2014). Pengaruh Struktur Kepemilikan Terhadap Profitabilitas Perusahaan Manufaktur di Indonesia. Jurnal Akuntansi Dan Keuangan, 15(1), 15-26. https://doi.org/10.9744/jak.15.1.15-26 